\title{
水平領域規模を考慮した気象要素と降雨の抽出 \\ EXTRACTION OF METEOROLOGICAL ELEMENTS AND RAINFALL CONSIDERING A HORIZONTAL SCALE OF A TARGET AREA
}

\author{
西山浩司 $1 \cdot$ 神野健二2 \\ Koji NISHIYAMA and Kenji JINNO \\ 1正会員 理修 九州大学助手 工学研究院 (广 812-8581 福岡市東区箱崎6丁目 10-1) \\ 2 正会員 工博 九州大学教授 工学研究院 (广 812-8581 福岡市東区箱崎6丁目10-1)
}

\begin{abstract}
Rainfall prediction technique based on short-range forecasts requires the construction of physically meaningful relationships between numerical model outputs and rainfall. However, it is questionable whether conventional rainfall prediction models incorporate the physically meaningful relationships because inherent horizontal scale in a meteorological field inducing a rainfall is not fully considered. Therefore, in our study, in order to relate meteorological elements (Precipitable water, Convergence, CAPE) to rainfall, a horizontal scale of a target area for extracting them was considered. As a result, a larger target area led to the construction of physically meaningful relationships between meteorological elements and rainfall. Therefore, it should be emphasized that the specification of the horizontal scale of target area, considering horizontal features of meteorological fields, plays an important role in constructing a reliable rainfall prediction model for practical use.
\end{abstract}

Key Words : Precipitable water, Convergence, CAPE, Rainfall prediction

\section{1.はじめに}

降雨予測の基本は, 過去の数值予報結果と雨量との因 果関係を統計的に関連づけるMOS (Model Output Statistics）と呼ばれる手法"1に基づいている. 弚の因果関 係は , 重回帰式によって表現される場合や , ニューラル ネットワークによる学習によって構築される場合もある． このようにして構筑された降雨予測モデルに, 新しい数 值予報結果が入力されて, 雨量や降水確率力出力される . この手法は，気象庁の予報システムの中では，半日〜1 日程度先を対象にした短期予報に利用されている，光の 予報結果は , 半日〜1日程度先に大雨が発生する恐れが ある場合に発令される大雨注意報のための情報源の一つ である.この予報は，現況から数時間先までを対象にし た短時間降水予報) (大雨洪水警報発令のための情報源 の一つ) と並んで, 防災上極めて重要な気象情報を与え る.従って，信頼性のある防災気象情報を提供するため には, 当然, 降雨予測モデルの信頼性を向上させること が必要不可欠である。

降雨予測モデルを構築する際, 精度を向上させること が最も重要であることは言うまでもないが, 前提条件と して, 数值予報結果と降雨の対応関係が, 物理的な因果
関係を十分反映していることか望まれる . しかし，多く の降雨予測モデル ${ }^{33,4), 5)}$ で , 単に , 観測点の雨量と近傍 格子の気象要素を対応させてデータを抽出し, 重回帰分 析の手法の一つである变数選択法を使って, 気象要素を 選択する方法力採用されている.この方法では，観測点 の雨量を光の近傍の気象要素と対応させている点に問題 があり，降雨を引き起こす物理的な因果関係を説明する ことか灘しいと考えられる.即ち，2節，5節の述べるよ うに, 各気象要素から構成される気象場や雨量分布には 特徵的な分布があり, 広範囲な分布, 局地的な分布 , 或 いは, バンド状の分布を示したりする．また，気象要素 自体にも独特な性質を持っている。例えば，安定度に関 連する指標で考えると，夏季日射の影響て積乱雲が発生 する場合には，発生前の成層状態は不安定である．一方， 前線帯では, 既に降雨を伴っているため, 不安定か解消 され，中立成層か汥配的になり，光の前面で不安定成層 になっている場合が多い．この場合は，“観測点の雨が 激しいから直上は不安定” とは言えない. 以上のような 特性を十分に考慮しておかないと，降雨を引き起こす物 理的な因果関係が，降雨予測モデルに十分に反映されず， 予測結果に対する信頼性か低下することか懸念される .

以上の問題点は, 気象要素と雨量の関係を抽出する領 域の規模を考慮することによって , 改善が可能であると 
考えられる. 乥こで, 本論文では, 従来の降雨予測モデ ルのように，一つの格子点を含む狭い領域（約 $20 \mathrm{~km}$ 幅) の場合と，さらに領域を拡大した場合を考慮して， 気象要素と雨量との対応関係を構築し，領域の規模に 従って, 弚の関係がどのように変化し, どの程度まで, 物理的に意味のある因果関係を説明することができるよ うになるか調へる.ここでは, 豪雨による災害が多発す る梅雨期を対象に解析力行われる .

\section{2 . 梅雨期の気象場の基本的特徵}

雨量と気象要素の対応関係を，梅雨期の気象場の基本 的な特徵 ${ }^{6}$ に基ついて抽出する . 梅雨期の豪雨は，下層 ジェットと呼ばれる強風帯を伴って現れる湿舌 (水蒸気 を多く含む領域) の領域で発生することが多い，湿舌は， 梅雨前線帯と一致し，常に大量の水蒸気の供給を受ける。 従って，不安定化した成層状態は，収束に伴う上昇流の 影響を受けると，対流活動の結果として解消され，中立 化する特徵を持っている.一方，雨量分布の特徽として は，梅雨前線の近傍で，1993年の鹿児島豪雨”や1982年 の長崎豪雨 ${ }^{8}$ を代表として , 幅50〜100km程度の規模を 持つバンド状，或いは光れと同規模の塊状の降雨分布9) ${ }^{10)}$ か現れ，兴の通過に伴って，短時間スケールで大量の 降雨がもたらされることが多い .

梅雨前線帯の降雨発生メカニズムは, 以上の特徵を含 め, 実際は, さらに複雑である.しかし, 基本的には, 水蒸気が十分含まれることによって, 深い対流活動を引 き起こすほどの不安定成層か形成されるか否か, また , 対流活動を引き起こす引き金があるか否かといった特徵 が, 降雨の発生を説明する指標を決定するための基本的 な基準となると考えられる，光こで本論文では，水蒸気 量と関連する指標として, 水蒸気量の鉛直積算量を表す 可降水量 (PW) , 対流活動の引き金となる指標として， 空気の収束 (CONV)，対流活動の状況を説明する安定 度指標として，気塊を1000hPa面から持ち上げて得られ る対流有効位置エネルギー (CAPE) ガ用いられる .

\section{3 . 気象要素と雨量の領域別抽出方法}

本論文では，気象要素に対しては，日本を含む東アジ ア域の気象庁領域客観解析データを使用する．一方，雨 量に対しては，レーダーアメダス解析雨量を用いる。領 域客観解析データ (GPV (Grid Point Value)) ) は，1日4 回 (日本時間 $3 ， 9 ， 15 ， 21$ 時) 作成され，水平 $20 \mathrm{~km}$ 間 隔, 鉛直方向に21層（地表面-10hPa）からなる.データ は, 気圧面ごとに, ジオポテンシャル高度 , 気温, 湿度 (湿数)，風向・風速によって構成される，一方，レー ダーアメダス解析雨量は, 気象レーダーによる反射因子

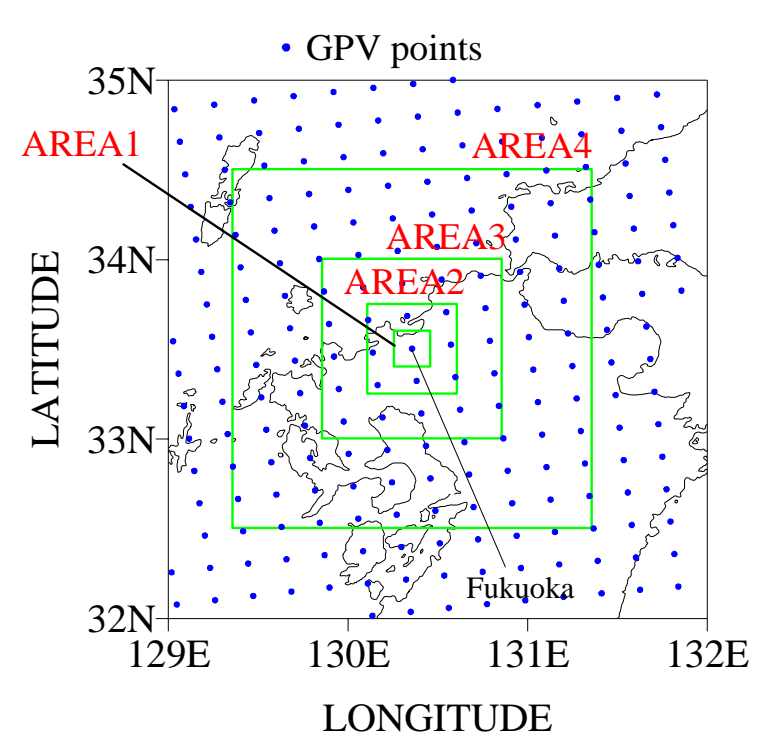

图-1 気象要素と雨量を抽出するための4つの対象領 域 . 各領域の中心は福岡市近傍のGPV点 .

表-1 各領域の大きさと光れに含まれるGPV点とレー ダーアメダス点の数 .

\begin{tabular}{|c|c|c|c|}
\hline 領域 & $\begin{array}{c}\text { 領域の大きさ } \\
\text { (緯度経度幅) }\end{array}$ & $\begin{array}{c}\text { GPV点 } \\
\text { の数 }\end{array}$ & $\begin{array}{c}\text { レーダーアメ } \\
\text { ダス点の数 }\end{array}$ \\
\hline AREA1 & $0.1^{\circ}$ & 1 & 12 \\
\hline AREA2 & $0.5^{\circ}$ & 9 & 80 \\
\hline AREA3 & $1.0^{\circ}$ & 25 & 320 \\
\hline AREA4 & $2.0^{\circ}$ & 101 & 1280 \\
\hline
\end{tabular}

表-2 気象要素と雨量の抽出方法.

\begin{tabular}{|l|l|}
\hline $\mathbf{P W}(\mathbf{m m})$ & 領域内最大值 \\
\hline $\operatorname{CONV}\left(\mathbf{s}^{-1}\right)$ & $\begin{array}{l}\text { 領域内の4気圧面 }(850,900,925,950 \mathrm{hPa}) \text { か } \\
\text { ら選ばれた最大の収束量 }\end{array}$ \\
\hline $\mathbf{C A P E}\left(\mathbf{m}^{2} / \mathbf{s}^{2}\right)$ & 領域内最大值 \\
\hline 雨量 $(\mathbf{m m} / \mathbf{h})$ & $\begin{array}{l}\text { GPV時間 }(0900,2100 J S T) \text { から3時間以内に得ら } \\
\text { れる領域内最大時間雨量 }\end{array}$ \\
\hline
\end{tabular}

から見積もられる $2.5 \mathrm{~km}$ 格子のレーダー雨量と, アメダ ス点て観測される実際の雨量を合成して得られる $5 \mathrm{~km}$ 間隔の格子雨量データである (2001年4月以降 $2.5 \mathrm{~km}$ 格 子) . 時間間隔は，1時間間隔 (2003年6月以降30分間 隔) である .ここでは，1996年から99年までの4年間を 対象にして, 各年6,7月のGPVか浰用される.この際, 1日2回 (日本時間の9時と21時) のGPVを利用し，合計 484ケース (4つの欠損ケースを除く) のGPVが使われる .

本論文では, 気象要素と雨量の対応関係を抽出するた め, 図一1に示されるような4つの対象領域を設定し, 表 -1で示される4つのケースについて, 雨量と気象要素の 対応関係を調べる . 図-1の各領域は, 福岡市に最も近 いGPV点を中心として領域の大きさ力設定されている . 

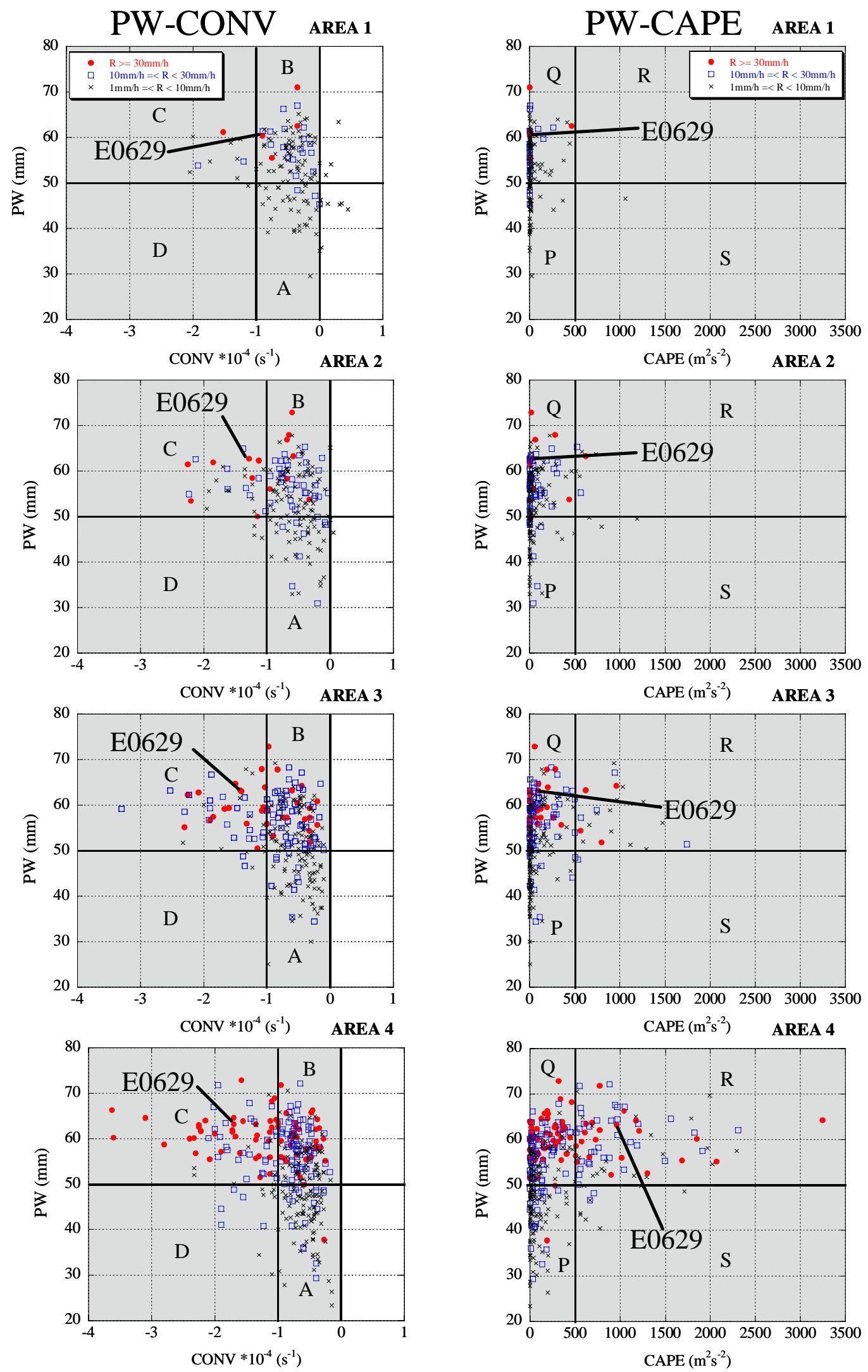

图-2 左側の図は, 雨量のPWとCONVに対する依存性が, 光して, 右側の図は, PWとCAPEに対する依存性か領域規模別に示 されている.前者では, $50 \mathrm{~mm} の \mathrm{PW},-1.0 \times 10^{4} \mathrm{~s}^{-1}$ のCONVを境にして , 4つの変数範囲 $(\mathrm{A}, \mathrm{B}, \mathrm{C}, \mathrm{D})$ を設定し，一方，後者で

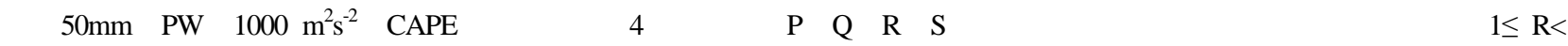
$10 \mathrm{~mm} / \mathrm{h} ， 10 \leq \mathrm{R}<30 \mathrm{~mm} / \mathrm{h}, \mathrm{R} \geq 30 \mathrm{~mm} / \mathrm{h}$ の 3 つ雨量カテゴリーに分けてプロットされている．また， E0629は，1999年6月29日 0900JSTに北部九州を襲った豪雨ケースを示す． 

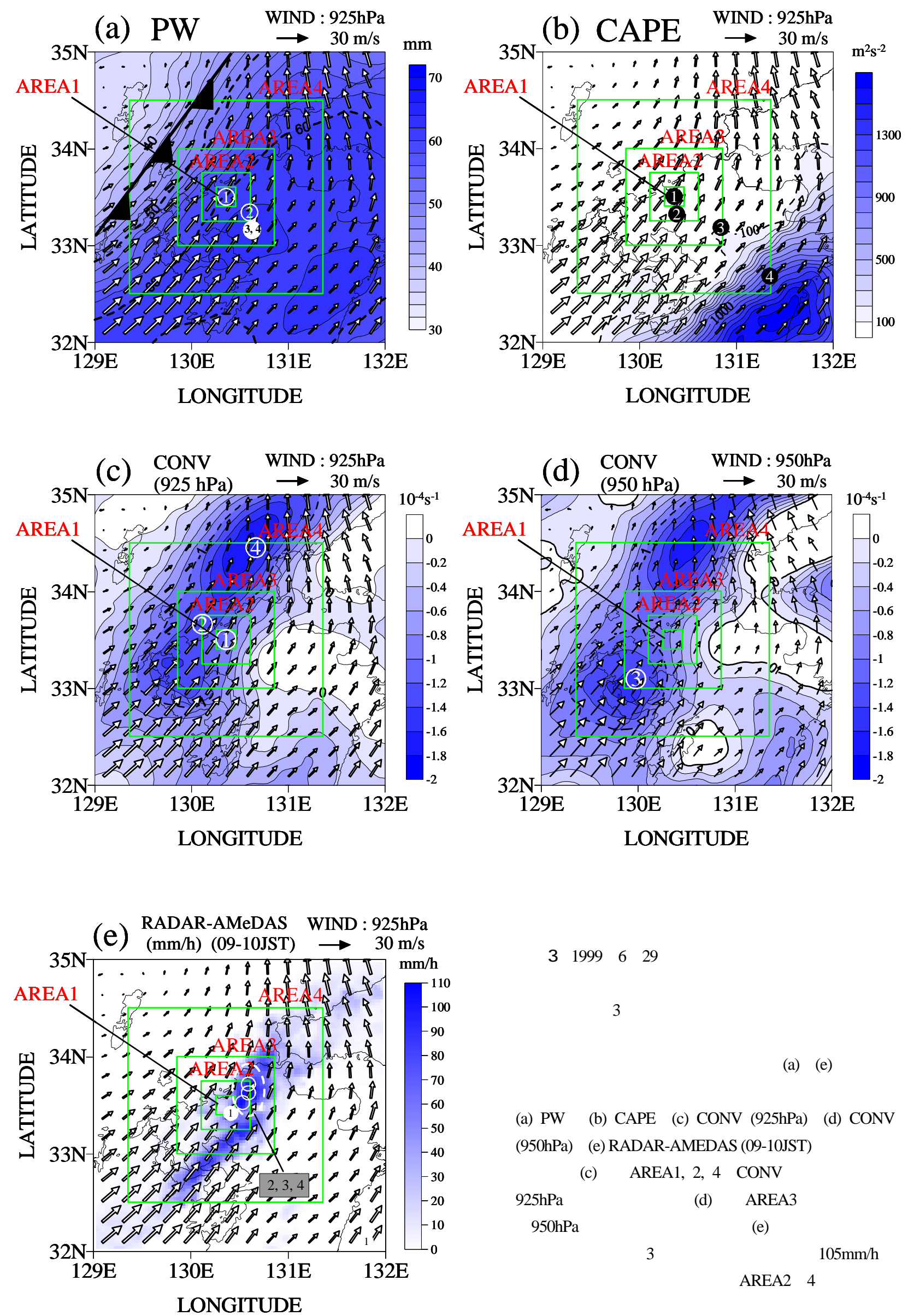

図－３1999年6月29日早朝, 北部九州を襲つた豪雨を 取り巻く気象場と雨量の水平分布が, 福岡市を中心と した緯度経度3度幅の領域内に描かれ, 各気象要素と 雨量の值力抽出された位置を, 設定領域の番号で表示 している. 弚れらの水平分布は, 次の $(\mathrm{a})$ ( (e)に示され る.
(a) PW , (b) CAPE , (c) CONV (925hPa), (d) CONV (950hPa) , (e) RADAR-AMEDAS (09-10JST)

ここで，(c)は，AREA1，2，4でCONVの最大を捉えた 925hPa面の収束を示し，(d)は，AREA3で最大を捉え た950hPa面の収束を示す．また，(e)で，破線の楕円の 中に描かれている3地点 $(\bigcirc)$ は, ともに $105 \mathrm{~mm} / \mathrm{h}$ を 記録した最大雨量地点を示し, AREA2〜4によって同 時に抽出されている. 
AREA1では，緯度経度幅 $0.2^{\circ}(\sim 20 \mathrm{~km})$ の水平規模を持 ち, 福岡市近傍のGPV点のみ含む．一方，AREA2 $\left(0.5^{\circ} \sim 50 \mathrm{~km}\right)$, AREA3 $\left(1.0^{\circ} \sim 100 \mathrm{~km}\right)$, AREA4 $\left(2.0^{\circ} \sim 200 \mathrm{~km}\right)$ のように領域力拡大するに従って, 内部 に含まれるGPV点とレーダーアメダス点は増加する . ま た, 気象要素と雨量の抽出方法は, 表-2に従う. PWと CAPEは , 各領域で最大值を抽出する .一方 , CONVは , 下層の4気圧面 $(850,900,925,950 \mathrm{hPa})$ から最大の収束 (マイナス值の絶対値の最大) を抽出する . 雨量の抽出 については, 降雨システムが, どの程度の時間内に対象 領域内を通過するかについて十分な検討が必要であるが， 今回は, GPVの設定時間 $(09,21 J S T)$ から3時間以内に， 対象領域内にもたらされる最大1時間雨量を抽出する .

\section{4 . 気象要素と雨量との領域別関連性}

本節では, 領域を拡大するに従って, 抽出される雨 量, 気象要素の值がどのように変化するか調べる . 図 2 には, 雨量のPW と CONV に対する依存性と, PW と CAPE に対する依存性力領域規模別に示されている.便 宜上, 前者では, $50 \mathrm{~mm}$ の PW, $-1.0 \times 10^{-4} \mathrm{~s}^{-1}$ のCONV を 境にして，4 つの变数範囲 $(\mathrm{A}, \mathrm{B}, \mathrm{C}, \mathrm{D})$ を設定し， 後者では, $50 \mathrm{~mm}$ の PW , $1000 \mathrm{~m}^{2} \mathrm{~s}^{-2}$ の CAPE を境にして， 4 つの範囲 $(\mathrm{P}, \mathrm{Q}, \mathrm{R}, \mathrm{S})$ を設定する . また , 図 - 2 の撒布図の各点は , $1 \leq \mathrm{R}<10 \mathrm{~mm} / \mathrm{h}, 10 \leq \mathrm{R}<30 \mathrm{~mm} / \mathrm{h}, \mathrm{R} \geq$ $30 \mathrm{~mm} / \mathrm{h}$ の 3 つの雨量カテゴリーに分けてプロットされ ている .これ以降, 关れらの力テゴリーを, 弱、降雨, 中程度の降雨, 強い降雨と呼ゔことにする。

最初に，雨量の頻度特性を見ると，領域を拡大すると， 弱い降雨の頻度が減少し, 中程度, 強い降雨の頻度力増 加することがわかる．炎の結果は，領域規模の拡大に 伴って, 領域内に中程度, 強い降雨を含む降水域を捉え る機会力増加することを意味する．次に，気象要素に関 して見ると, CONVの場合は, 領域拡大に従って, 大き な值を抽出する頻度か増加する．一方，CAPEの場合は， AERA3以下の領域で, 抽出される值が小さく, AREA4 で, 大きな值を抽出する頻度か㴔激に増加する．また， PWの場合は, 強い降雨で，領域規模に関係なく，50mm 以上の範囲に分布する.この特徵は, 下層が十分湿って いる場合, 或いは, 対流活動の結果として, 下層から上 層に至るまで湿度が100\%に近い雲域を示す場合に現れ， 梅雨期・夏季の気象場の特徵を反映している．以上より， 強い降雨は, 領域の拡大に伴って, 図-2のB, Cの範囲 と, $\mathrm{Q}, \mathrm{R}$ 範囲で, 大きな頻度を示すことがわかる。

\section{5 .気象場の特徵に基づく因果関係の考察}

前節て述べたように，領域規模の拡大に伴って，気象
要素と雨量との関係力明瞭になることがわかった . その 因果関係は，気象場の特徵によって説明されることは言 うまでもない. 即ち, 図-2に示された関係は, 梅雨 期・夏季の気象場の特徵が含まれ，梅雨前線帯や台風の 影響を受けたケースや，日射による影響を受けたケース など多くのパターンが含まれる．乥こで，本節では， 1999 年 6 月 29 日早朝, 福岡市に豪雨をもたらした気象 場の特徵を例にとって，領域規模別に抽出された気象要 素と雨量との関係が, 実際の気象場に基ついた因果関係 をどの程度まで反映することか可能になるか調べる．表 -3には, 図-2の E0629 に対応する気象要素 (PW , CONV，CAPE) と雨量の值か領域規模別に示されてい る.また, 図一-3に, 緯度経度 3 度幅の領域内で各気象 要素と雨量の水平分布か渵力れ, 表-3に記載された值 の抽出された位置が，設定領域の番号で表示されている .

表 - 3 1999年6月29日0900JSTの豪雨イベントを対象に して,4つの領域から抽出された気象要素 (PW， CONV , CAPE) と雨量の值 .

\begin{tabular}{|l|c|c|c|c|}
\hline & AREA1 & AREA2 & AREA3 & AREA4 \\
\hline PW(mm) & 60.4 & 62.7 & 63.2 & 63.2 \\
\hline CAPE $\left(\mathbf{m}^{2} / \mathbf{s}^{2}\right)$ & 0 & 27.7 & 92.1 & 961.3 \\
\hline $\operatorname{CONV}\left(\mathbf{1 0}^{-4} \mathbf{s}^{-1}\right)$ & -0.9 & -1.28 & -1.42 & -1.7 \\
\hline RAIN $(\mathbf{m m} / \mathbf{h})$ & 51 & 105 & 105 & 105 \\
\hline PW vs CONV & B & C & C & C \\
\hline PW vs CAPE & Q & Q & Q & R \\
\hline
\end{tabular}

このイベントで発生した豪雨は, 典型的な゙湿舌の場 で発生した . 図一３にに示されるように，湿舌に相当す る南東側で, 風速が大きい下層ジェットを伴って, PW が $50 \mathrm{~mm}$ を超える領域になっている。一方, 弚の北西 側では, 乾燥空気が流入して, PW の水平勾配が大き 領域 (地上天気図では寒冷前線力澥析されている) 力存 在し, 南西から北東に延びる収束域に対応している (図 -3c，d) .さらに，この収束域の南側には豪雨域 (図

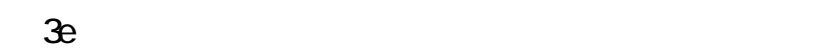
豪雨を引き起こすような深い対流力発達したと考えられ る.この特徵は, 大気の成層状態にも影響する. 対流が 起こると中立に近い成層状態になり，理論上 CAPE は 小さくなる . 谷のため, 図-3bに示されるように , 豪 雨域で, CAPE が $100 \mathrm{~m}^{2} \mathrm{~s}^{-2}$ 以下の小さい值を示したと考 えられる.実際，このイベントでは，数值モデルによる 解析 ${ }^{11)}$ によって，中立に近い成層状態力豪雨域に存在 したことか確忍されている．反対に，CAPE の大きい領 域は, 豪雨域から離れた領域 (豪雨域の南東側) に存在 する.この領域は, 前線に対して, 水蒸気を供給する領 域として特徵つけられる. 兴の成層状態は, 下層が湿つ て, 対流力起こっていない状態であることから, 対流不 安定を示し，CAPE の值が大きい特徵を持っている. 
従って，この領域の空気力収束域に流入し，対流活動を 誘起し，大気を中立化することを考慮すれば，豪雨域か ら離れた安定度も，豪雨の指標として有効である可能性 があり, 十分検討する余地がある。

次に, 以上の豪雨を引き起こした気象場が，設定し た領域（AREA1〜4）内で，どのように捉えられている か, 気象要素別に考察する.PW (図 - 3a) の場合， AREA3 , 4 で湿舌と PW の勾配が大きい前線の特徵を 十分に捉えている. また，湿舌の広範囲な分布のため， 領域規模に関係なく，大きな PW を抽出可能となる． 一方, CONV (収束域) の場合 (図 - 3c, d) は, AREA4 によって十分捉えられ, AREA3 も強い CONV を含む領域を捉えている．しかし，収束域は，バンド状 て横幅力狭いため, 設定領域が小さくなると，収束域を 十分に捉えられなくなる. 兴の影響で, AREA1 は, 2 つの強い収束域に挟まれ，結果的に，弱いCONV の值 しか抽出できないことがわかる.CAPE の場合 (図 3b）, AREA3 よりも小さい領域では, 豪雨域の対流活 動の影響で, 小さい CAPE しか抽出できないことがわ かる.しかし，AREA4 まて拡大すると，豪雨域の南東 側に存在する大きな CAPE の領域 (豪雨域への水蒸気 の流入域) を含むようになる.最後に雨量 (図-3e) に 関しては, AREA3，4 で，豪雨域を十分捉えている． 一方, AREA2 では, 豪雨域の一部しか捉えていないが， その領域内を豪雨域力通過していた影響で, 大きな雨量 を含む領域を捉えることができている．従って， AREA2〜AREA4 で, 豪雨域の最大雨量 $105 \mathrm{~mm} / \mathrm{h}$ を抽 出することができた．しかし，領域規模が小さい AREA1 では, 近傍を $105 \mathrm{~mm} / \mathrm{h}$ の雨量を含む豪雨域が通 過しているにも関わらず， $105 \mathrm{~mm} / \mathrm{h}$ の雨量を抽出する 機会を失い, $51 \mathrm{~mm} / \mathrm{h}$ の雨量を抽出する結果になってし まった .

\section{6 ．結論}

本論文では, 従来の降雨予測手法のように,一つの格 子点を含む狭い領域 (約 $20 \mathrm{~km}$ 幅) の場合と，さらに領 域を拡大した場合を考慮して, 気象要素と雨量との対応 関係を構筑し，領域の規模に従って，兴の関係がどのよ うに変化し，実際の気象場に基ついた因果関係をどの程 度まで反映することが可能になるか調べた。

その結果，領域規模の拡大によって，気象要素と雨 量との関係が, 実際の気象場の特徵を概ね反映するよう になった。従って，領域力狭いと，豪雨に関連する気象 場の特徵と強い降雨域があっても，両方とも捉えられる こともあれば，どちらか一方だけ捉えられる，或いは両 方とも捉えられなくなる危険性を把握しておく必要があ る.さらに, 気象要素と雨量との良好な関係を得るため には, 弚れらの分布の特徵も考慮する必要がある. 例え
ば, 湿舌内の可降水量を捉える場合には，勾配力緩やか な水平分布を考慮すると，領域を大きく設定する必要は ない，また，収束や降雨を捉える際には，前線に沿った 形て横幅力浃いッ゙ンド状の特徵を示すことを考慮に入れ て , 領域を大きく設定する必要がある.安定度指標の場 合は, 前線帯の降雨域で中立, 光の前面て対流不安定に なるように，対流の段階で大きく成層状態力異なる。こ のような固有な性質を考慮しつつ, どの領域の安定度指 標と降雨力関連するかについて十分な考察を行い, 安定 度指標を抽出する領域の位置と規模を決める必要がある。 このように , 信頼性のある降雨予測手法を構築する ためには, 気象要素自体力特つ固有の性質と炎の分布特 性を考慮に入れて, 各気象要素別に，領域の位置と規模 を設定すること，光して，雨量に関しても，バンド状， クラスター状の分布特性を考慮に入れて，領域規模を決 めることが重要である.従って, 以上示した点を降雨予 測手法に十分反映させなければ, どんなに精錬された手 法であっても，予測結果の信頼性の低下を招く恐れがあ ることを十分認識しなければならない .

\section{参考文献}

1) Glahn, H, R., Lowry, D. A. : The use of Model Output Statistics (MOS) in objective weather forecasiting. J. Appl. Meteor, 11, pp. 1203-1211, 1972.

2) Wilson, J. W. : Precipitation nowcasting : Past, Present and Future. Proceedings of International Symposium on Hydrological Application of Weather Radar, Melbourne, Australia, 8pp (CDROM), 2004.

3) Kuligowski, R. J., Barros. A. P. : Localized precipitation forecasts from a numerical weather prediction model using artificial neural network. Weather and Forecasting, 13, pp. 1194-1204, 1998.

4) Hall, T., Brooks, H. E., Doswell, C. H. : Precipitation forecasting using neural network. Weather and Forecasting, 14, pp. 338-345, 1999.

5) 気象庁: 平成8年度量的予報資料 (2章), 気象業務支援セン ター, 78pp, 1996.

6) 吉崎正憲, 村上正隆, 加藤輝之 : メソ対流系, 気象研究ノー 卜, 386pp , 2005.

7) Kato, T. : Numerical simulation of the band-shaped torrential rain observed over southern Kyushu, Japan, on 1 August 1993. J. Met. Soc. Japan, 76, pp. 97-128, 1998.

8) Ogura, Y., Asai, T., Dohi, K. : A case study of a heavy precipitation events along the Baiu front in Northern Kyushu, 23 July 1982: Nagasaki heavy rainfall. J. Met. Soc. Japan, 63, pp. 883-900, 1985.

9) 吉崎正憲 : メソ対流系 ( I ), 天気, 46 , pp.783-790，1999.

10) 吉崎正憲 : メソ対流系 (II ) , 天気, 46 , pp.833-841，1999.

11) Kato, T. : Structure of the band-shaped precipitation system inducing the heavy rainfall observed over northern Kyushu, Japan on 29 June 1999. J. Met. Soc. Japan, 84, pp. 129-153, 2006.

(2006. 9. 30受付) 